\begin{tabular}{|l|l|l||}
\hline \multicolumn{2}{|c|}{ PublisherInfo } \\
\hline \hline PublisherName & $:$ & BioMed Central \\
\hline \hline PublisherLocation & $:$ & London \\
\hline \hline PublisherImprintName & $:$ & BioMed Central \\
\hline \hline
\end{tabular}

\title{
Methylation in flies
}

\begin{tabular}{|l|l|l||}
\hline \multicolumn{2}{|c|}{ ArticleInfo } \\
\hline \hline ArticleID & $:$ & 3874 \\
\hline \hline ArticleDOI & $:$ & $10.1186 /$ gb-spotlight-20001227-02 \\
\hline \hline ArticleCitationID & $:$ & spotlight-20001227-02 \\
\hline \hline ArticleSequenceNumber & $:$ & 311 \\
\hline \hline ArticleCategory & $:$ & Research news \\
\hline ArticleFirstPage & $:$ & 1 \\
\hline \hline ArticleLastPage & $:$ & 2 \\
\hline \hline & & RegistrationDate : 2000-12-27 \\
ArticleHistory & $:$ & OnlineDate $\quad$ 2000-12-27 \\
\hline \hline ArticleCopyright & $:$ & BioMed Central Ltd2000 \\
\hline \hline ArticleGrants & $:$ & \\
\hline \hline ArticleContext & $:$ & 130591111 \\
\hline \hline
\end{tabular}




\section{Jonathan B Weitzman}

Email: jonathanweitzman@hotmail.com

It is a widely held belief that flies do not contain methylated DNA. This has always been a concern to those championing the critical role played by DNA methylation in mammals. In the December EMBO Journal Gowher et al. describe a sensitive assay to detect 5-methylcytosine in Drosophila melanogaster and put an end to the controversy (EMBO J 2000, 19:6918-6923). The technique involves multiple steps including the enzymatic degradation of DNA to nucleosides, separation of 5-methylcytosine by reversed-phase high-performance liquid chromatography (HPLC), radiolabeling with deoxyribonuclease kinase $(\mathrm{dNK})$, followed by two-dimensional thin-layer chromatography analysis. The authors detected 5-methylcytosine in all stages of fly development and estimate that the amount of methylated cytosine bases is 50 times lower than in humans. These observations clearly dispel the methylation myths and help to explain the recent discovery of putative methyltransferase and methylcytosine binding proteins in Drosophila.

\section{References}

1. EMBO Journal, [http://www.emboj.org]

2. Drosophila proteins related to vertebrate DNA (5-cytosine) methyltransferases.

This PDF file was created after publication. 